\title{
Volume 24 Number 2
}

\section{9}

\section{Children}

\section{Australia}

\section{In this issue ...}

What makes good outcomes for children in foster care

\section{Children's contact services}

On servicing and respecting children's identity

Why don't they become foster carers?

A study of people who inquire about foster care

'It must be because ...'

Non-biological care and mental health

Part III Who refers - and why?

Marxist and feminist critiques of child protection

To protect children or to change society?

Supporting male parents

Children have rights even when they do wrong 


\section{Children Australia}

Volume 241999

\section{EDITOR: Lloyd Owen}

Senior Lecturer

Dept of Social Work \& Social Policy

La Trobe University

BOOK REVEW EDTIOR: Dr June Allan

Senior Lecturer

Schiool of Social Science \& Planning, RMIT
Children Australia is a quarterly journal which aims to provide on opportunity for service providers, academics and others concerned with children and families to report on their work, to raise issues and to share their views.

The opinions expressed in Children Australia are those of its contributors and are therefore not necessarily those of the Editor or members of the editorial board.

\section{NATIONAL EDITORIAL BOARD}

\section{ACT}

New South Wales

Northern Territory

Queensland

South Australia

Tasmania

Victoria

Western Australia

Adviser

Asia-Pacific Region

Dr Howard Bath Executive Director, Marymead Child \& Family Centre

Dr Elizabeth Fernandez Senior Lecturer, School of Social Work University of New South Wales

Dr Sharon McCallum Senior Lecturer, Social Work, Faculty of Law, Arts \& Business Northern Territory University

Ms Chris-Maree Sultmann

Program Development Co-ordinator, Families Program Department of Families, Youth \& Community Care

Dr Freda Briggs

Professor of Child Development

School of Psychology

University of South Australia

Ms Scilla Weber

Consultant for Policy and Project Management

Child, Youth and Family Support

Department of Health and Human Services

Ms Margarita Frederico

Senior Lecturer, Department of Social Work \& Social Policy La Trobe University

Dr Chris Goddard

Director, Child Abuse and Family Violence Unit

Monash University

Dr Tom Keating

Pro Vice Chancellor, Wodonga Campus

La Trobe University

Dr Frank Ainsworth

Senior Lecturer, Dept of Community Services \& Social Sciences

Joondalup Campus

Edith Cowan University 


\section{CONTENTS}

Editorial.. 2

What makes good outcomes for children in foster care 4 Roslyn Leahy, Claerwen Little, Linda Mondy \& Dianne Nixon

Children's contact services.

On servicing and respecting children's identity

Emilia Renout

Why don't they become foster carers?

A study of people who inquire about foster care

Louise Keogh and Ulla Svensson

'It must be because ...'

Non-biological care and mental health. Part III. Who refers - and why?

Cas O'Neill and Deborah Absler

Marxist and feminist critiques of child protection

To protect children or to change society?

Philip Mendes

Supporting male sole parents

Book reviews.

DD The family of adoption

M Patterns of adoption: Nature, nurture and psychosocial development

Not the last word: point and counterpoint

Children have rights even when they do wrong

(and even when they are called Rat Boy, Blip Boy, Spider Boy and Boomerang Boy)

Chris Goddard

\begin{tabular}{|cc|}
\hline \multicolumn{2}{|c|}{1999 SUBSCRIPTIONS } \\
Standard & $\$ 55 \mathrm{pa}$ \\
Concession & $\$ 40 \mathrm{pa}$ \\
Overseas & $\$ 75 \mathrm{pa}$ \\
For further information, or to advise change of address, please contact: \\
Larraine Redshaw Tel: (03) 97921301 Fax: (03) 97921550
\end{tabular}

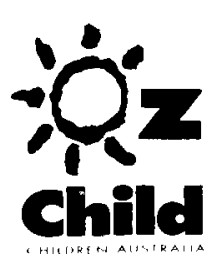

The financial support of Oz Child: Children Australia

is gratefully acknowledged

The financial support of the

La Trobe University Publications Committee is gratefully acknowledged 